\title{
Subdivisào do Pré-Cambriano da Amazônia; uma sugestão
}

\author{
João Orestes Schneider Santos (")
}

\begin{abstract}
Resumo
Até o presente, o Pré-Cambriano da Amazônia tem sido subdividido em três intervalos maiores: Superior, Médio e Inferior, com limites correspondentes a 2.600 m.a. e $1.800 \mathrm{~m} . \mathrm{a}$. Diversos trabalhos executados pela CPRM para o DNPM, juntamente com as informaçōes do Projeto RADAM, permitiram que fosse esboçada nova subdivisão para o Pré-Cambriano, fundamentada no reconhecimento e caracterização de diferentes ciclos tectônicos de amplitude continental e sua correlação com movimentaçōes da crosta em outros continentes. Assim, o Pré-Cambriano, a exemplo do adotado no Canadá, Austrália, Africa do Sul, Rússia, China e outros paises de extensas dimensōes territoriais, é subdividido em dois intervalos maiores: Arqueozóico e Proterozóico. O primeiro encerra dois ciclos tectônicos principais, um decorrido no Arqueozóico Inferiōr (+ de $3.000 \mathrm{~m} . \mathrm{a}$. ), denominado Guriense $( \pm 3.100$ m.a.) e outro relatado ao Arqueozóico Superior (2.600. 3.000 m.a.). Aroense $(2.600-2.800$ m.a.). O Guriense caracteriza-se por rochas de fácies granulitico, cujo melhor representante é o Complexo de Imataca na Venezuela, enquanto o Aroense representa os cinturōes anfiboliticos como Anauá (Roraima), Cuiú-Cuiú (Pará) Moura (Amazonas), Kanuku (Guiana), Supamo (Venezuela) e Coeroene (Suriname). O ciclo Transamazônico (2.000 $-2.200 \mathrm{~m}$.a.) é referido ao Proterozóico Inferior (2.600 a $1.900 \mathrm{~m} . \mathrm{a}$.), correspondendo aos "greenstone belts" e rochas itabiriticas dos grupos Cauarane (Roraima), Tunuí (Amazonas), Grāo Pará (Pará), Vila Nova (Amapá), Barama (Guiana), Pastora (Venezuela), Armina (Suriname) e Orapu (Guiana Francesa). Esta fol a úlma orogênese que afetou a Amazônia, pois, a partir de $\pm 1.900 \mathrm{~m}$.a. todos os processos evolutivos da Plataforma foram de caráter cratogênico. No Proterozóico Médio incidiram as reativaçōes Uatumā $( \pm 1.800$ m.a.) e Parguazense ( $\pm 1.500 \mathrm{~m}$.a.), manifestadas por intenso magmatismo ácido, sendo o limite entre o Proterozóico Médio e Superior estabelecido pelo Episódio Tectono-Termal K'Mudku ( $\pm 1.200 \mathrm{~m} . \mathrm{a}$. ), também conhecido como Madeirense (Rondônia), Nickerie (Suriname), Jari-Falsino (Amapá) e Orinoquense (Venezuela). No início do Protorezóico Superior outra reativaçăo conduziu a plutonismo ácido e intenso magmatismo básico-alcalino, caracterizando o Episódio Rondoniense ( $\pm 1.000 \mathrm{~m} . \mathrm{a}$. ), com os granitos Rondonienses e rochas básicas tipo Pacaás-Novos (Rondônia), Lábrea e
\end{abstract}

rio Pardo (Amazonas) e Cachoeira Seca (Pará). Ainda no final do Proterozóico, ocorreu outra reativação ainda pouco conhecida, a qual pode ser associada com o Brasiliano, representando a sedimentaçăo Prosperança e as Alcalinas Guariba ( \pm 600 m.a.).

\section{INTRODUÇÃO}

A CPRM tem executado na Amazônia uma série de projetos de geologia, os quais, em quase sua totalidade, são desenvolvidos em áreas pré-cambrianas. A despeito de nos últimos anos terem sido propostas em todo o mundo diversas escalas subdividindo o Pré-Cambriano, ainda não foi uniformizada uma seqüência geocronológica definida para a Amazônia, tendo sido adotada, geralmente a escala proposta por Almeida et al. (1968). Os dados obtidos até o presente permitem abordar alguns aspectos do pré-cambriano amazônico e esboçar uma escala geocronológica para a região, baseada na identificação de períodos de maior atividade tectono-termal. Pretende-se assim, a guisa de sugestão, propor a adoção, pela CPRM, de uma subdivisão, para o Pré-Cambriano da Amazônia, a qual deverá sofrer aprimoramento a partir de informaçōes e sugestões advindas de outras entidades que pesquisam na regiăo.

A escala proposta baseia-se principalmente em subdivisões já adotadas em países vizinhos, principalmente na Guiana e Venezuela, e no reconhecimento dos principais períodos diastróficos continentais, também já identificados naqueles países e, em parte, no Brasil. É feita uma comparação com as escalas e sucessão de everitos registrados em outras áreas cratônicas, cujo resultado demonstra a existência de períodos de movimentaçăo de caráter intercontinental.

$\left({ }^{\bullet}\right)$ - Companhia de Pesquisas de Recursos Minerais - CPRM, Manaus. 
O ARQUEOZÓICO E O LIMITE

ARQUEOZÓICO/PROTEROZÓICO

A fase mais antiga de intensa atividade térmica que é identificável em todas as grandes áreas cratogênicas do mundo, representa o fechamento da última orogênese arqueozóica $(2.500$ a $2.700 \mathrm{~m} . \mathrm{a}$.$) . Os valores radio-$ gênicos obtidos em rochas formadas durante essa época de movimentação, podem ser adotados como o limite mínimo inferior para o Proterozóico. Idades mais antigas ainda (acima de $3.000 \mathrm{~m} . \mathrm{a}$.), têm sido registradas em algumas partes do globo, todavia na Amazônia, até o presente, valores de tal amplitude são bastante esparsos, principalmente no Brasil, não podendo ser caracterizada a definição de uma fase de movimentação. No território de Roraima, Mandetta (1970a) registrou um valor de $4.402 \pm 89 \mathrm{~m}$.a. em anfibolito, coletado na região da serra da Cigana, e Amaral (1974) cita um valor de $3.283 \pm 113 \mathrm{~m}$.a. determinado em anfibolito coletado na regiáo da Serra dos Carajás. Nos países fronteiriços com a região norte da Amazônia, é definido um episódio relacionado ao Arqueano Inferior, denominado Guriense ( 3.000 a 3.400 m.a.).

McConnell (1972) definiu o Arqueano no Escudo das Guianas como sendo mais antigo que $2.500 \mathrm{~m}$.a., valor que utilizou como limite entre o Arqueano e o Proterozóico Inferior. Aquela era, para esse autor, está representada na Guiana Francesa pela Série Ille de Cayenne; no Suriname pela Formação Adampada-Falawatra; no Brasil pelos granulitos do rio Falsino; na Venezuela, pelo Complexo Imataca e finalmente, na Guiana, pelo Granito Makarapan e pelo Grupo Kanuku, além de granitos e gnaisses parcialmente remobilizados durante o episódio Akawaian.

Snelling \& Berrangé (1970), incluíram o Granito Makarapan no Grupo Kanuku, atribuindo âo primeiro uma idade de $2.595 \mathrm{~m}$.a. Posteriormente, Berrangé (1973), relacionou o Complexo Proto-Kanuku com o episódio Imataca, representando o último período de intensa atividade orogênica no Arqueano - com sedimentação geossinclinal e atividade plutô- nica associada - posicionado no intervalo de 3.100 a $3.400 \mathrm{~m} . \mathrm{a}$.

No Brasil, via de regra, as rochas mais antigas da Amazônia têm sido referidas ao "Complexo Basal", com idade oscilando do Pré-Cambriano Médio a Inferior.

Almeida et al. (1968), consideram o valor de $2.600 \mathrm{~m}$. a. como o limite entre o Pré-Cambriano Médio e Inferior. Hurley et al. (1968) admitem que esse valor situa-se entre dois ciclos orogênicos, um do Pré-Cambriano Médio (Ciclo Transamazônico -1.800 a 2.600 m.a.) e outro do Pré-Cambriano Inferior (t de 2.600 m.a.).

Santos et al. (1975) consideram que o complexo Xingu pode relacionar-se com o $\mathrm{Ci}$ clo Guriense, embora tal hipótese não tenha sido comprovada por datações radiométricas. pois os valores mais jovens que $2.600 \mathrm{~m}$.a. obtidos, provavelmente representam rejuvenescimentos ocasionados por eventos mais modernos.

Burwash (1969) cita que a orogenia mais antiga, amplamente preservada no hemisfério norte, tem sido datada por vários métodos entre o intervalo 2.500 e $2.700 \mathrm{~m}$. a. (Quadro I).

No Escudo Canadense, a orogenia Kenoriana é situada em torno de $2.500 \mathrm{~m}$.a., de acordo com Stockwell (1969). Na Groenlândia, rochas dessa orogênese, dos fácies anfibolito e granulito, foram situadas no intervalo 2.500 a 2.700 m.a. No sul do Canadá, a orogenia Algomaniana foi posicionada por Goldish (1969) no intervalo de tempo correspondente a $2.400-2.750 \mathrm{~m}$.a. Para o Escudo Ucraniano, Semenenko et al. (1969) reconheceram uma fase orogênica mais antiga, com $2.600 \pm 100 \mathrm{~m}$.a. Mesmo valor foi encontrado por Gerling et al. (1968) no Escudo Báltico.

Nos Estados Unidos, o limite inferior do Pré-Cambriano $X$, na escala proposta por James (1972) e adotada pelo U.S. Geological Survey, situa-se em torno de 2.500 m.a.

A base do Proterozóico no Canadá identifica-se com a base do Afebiano, determinada em 2.560 (2.690?) m.a., enquanto que na 


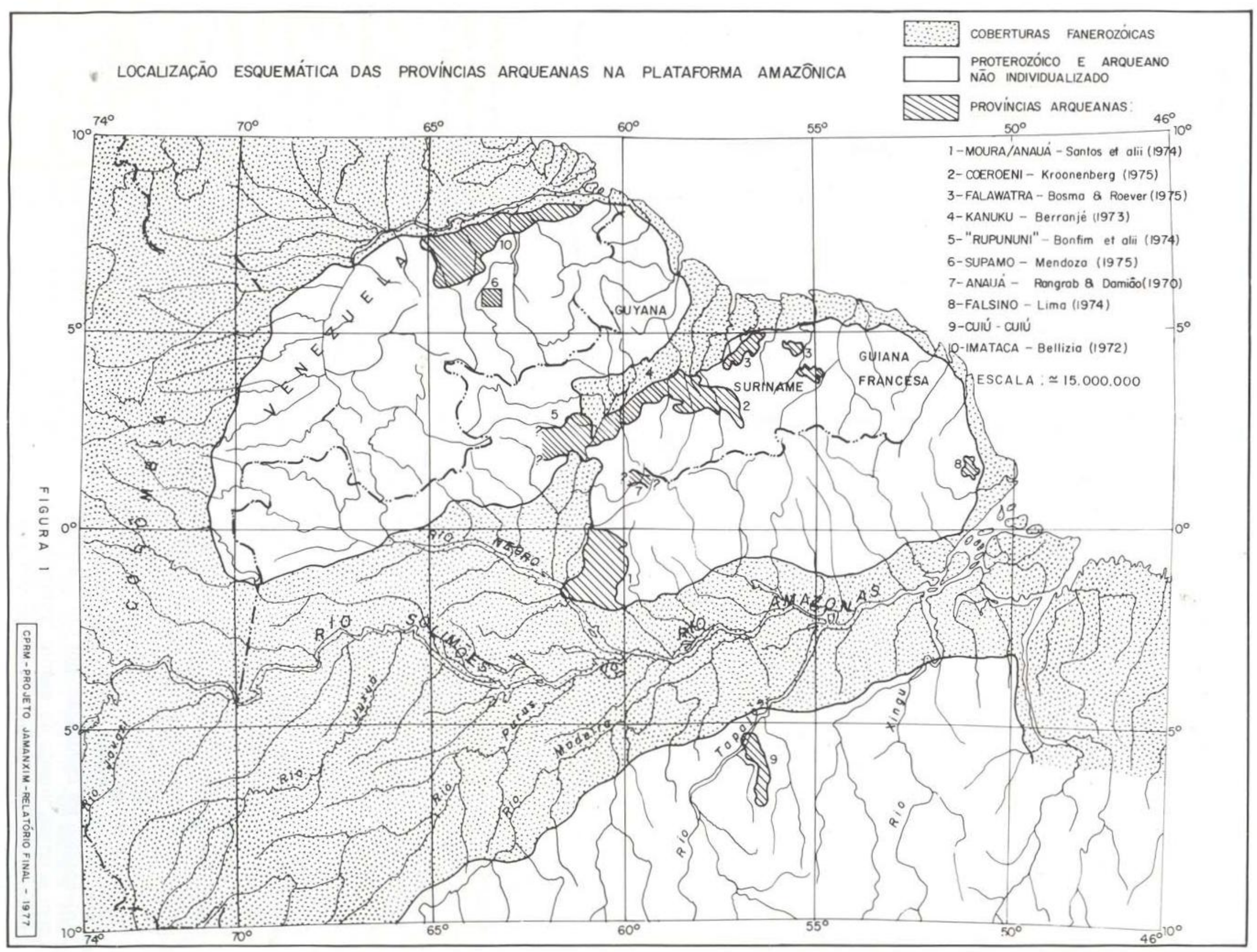




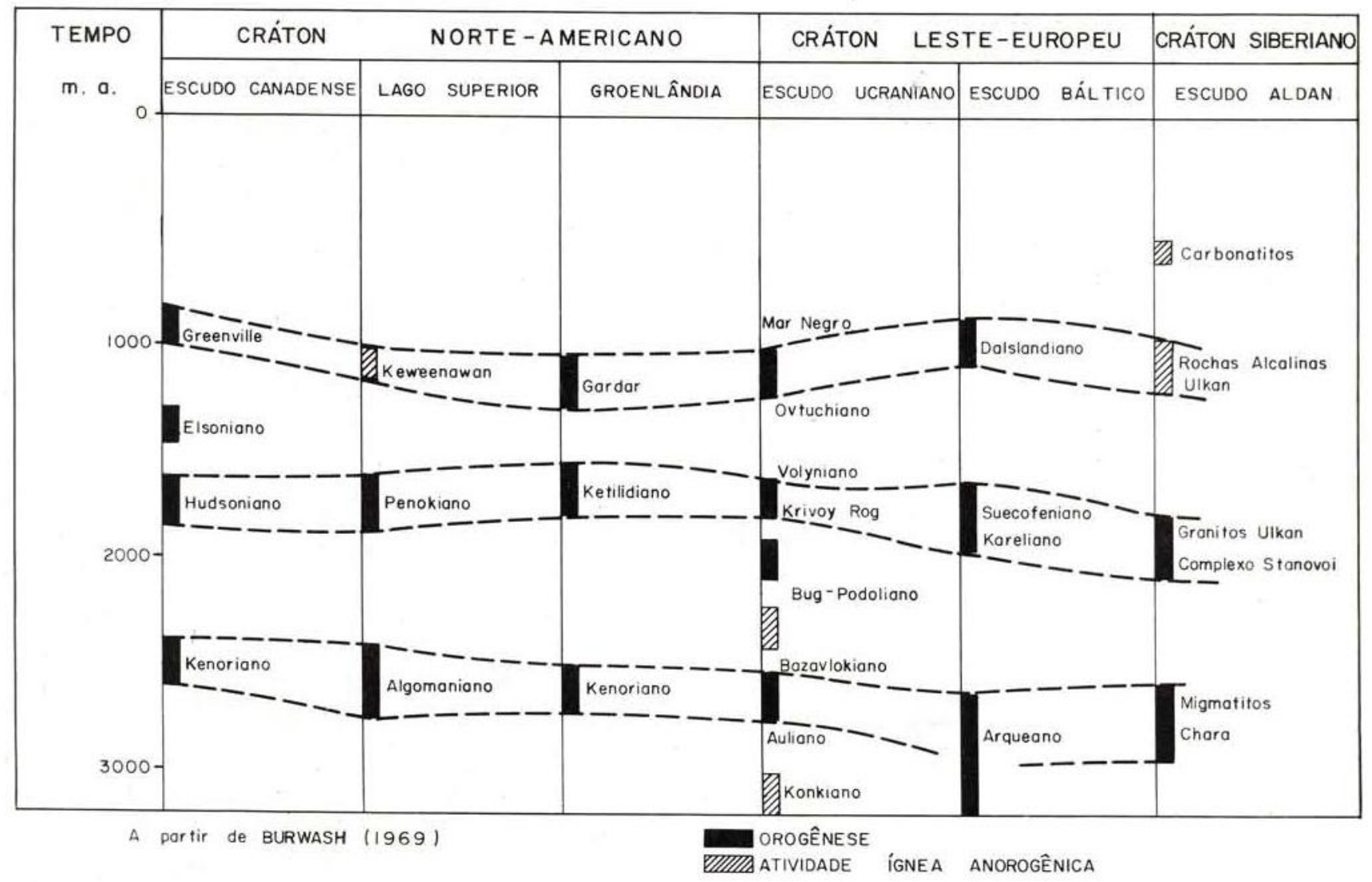

QUADRO I - Idades isotópicas comparativas. Escudos do Hemisfério Norte

União Soviética tal intervalo é posicionado em 2.700 m.a. por Semikhatov (1974).

McDonnell (1972), registra para a Africa, um período de máxima atividade tectono-termal Pré-Ubendiano, na faixa de $2.300 \mathrm{e}$ 2.700 m.a.

Nesse continente, dois principais episódios tectono-termais arqueanos são citados por Bellizzia (1972), sendo o mais jovem denominado Zagoride $(2.500$ a 2.650$)$, cronologicamente correspondente ao Aroensis da América do Sul e o mais antigo designado Liberiano ( $\pm 3.100 \mathrm{~m}$.a.), perfeitamente correlacionável em idade ao Evento Guriense. Na região sul da África o limite entre o Proterozóico e o Arqueozóico foi identificado por Clifford (1967) com o encerramento do evento tectono-termal denominado Shamvaiano (2.650 \pm 200 m.a.).
Observando-se a escala cronológica do Proterozóico da Austrália, verifica-se que a base dessa era, conforme Dunn et al. (1966), foi situada $\mathrm{em} \pm 2.300 \mathrm{~m}$.a.

Do breve apanhado acima, conclui-se que o valor de $2.600 \mathrm{~m}$.a., proposto por Almeida et al. (1968) tem grande correspondência nas principais áreas cratogênicas do globo. Observa-se também (vide Quadro II) uma quase unanimidade no emprego da subdivisão maior do Pré-cambriano em Proterozóico è Arqueano ou Arqueozóico, em detrimento das subdivisões $A, B, C$ e $D: X, Y$ e Z: Inferior, Médio e Superior. Estas últimas são empregadas principalmente nos Estados Unidos e na Europa Ocidental, enquanto a primeira é adotada pela maioria dos autores da União Soviética, Canadá, Africa, Austrália, Guiana, Venezuela e Escudo Báltico. 
Na Amazônia Brasileira, dispöe-se de poucos valores geocronológicos relacionados ao Arqueano, fato que é explicável pela existência de várias fases de movimentação no Proterozóico, ocasionando rejuvenescimentos radiogênicos de grande parte dos antigos núcleos polimetamórficos. Vários eventos provocaram esse fenômeno, dos quais, o mais importante, sem dúvida, foi o ciclo orogênico Transamazônico. Boa parte, portanto, das idades isotópicas obtidas para o Proterozóico Inferior (ciclo Transamazônico), podem ser interpretadas como valores pós-cristalinos (definição de Burwash, 1969), originados pela superposição de pelo menos dois grandes eventos diastróficos.

Na Venezuela, o Complexo Imataca é o representante da era arqueozóica, sendo constituído por gnaisses, anfibolitos, quartzitos, itabiritos, metamorfisados no fáceis almandina-anfibolito e granulito, ocorrendo, de acordo com Loczy (1973), granitos em áreas restritas. A idade desse complexo foi situada em 2.700 m.a., conforme Hurley et al. (1968). Todavia, posteriormente, foi-lhe atribuída uma idade de $3.000 \mathrm{~m}$.a. a $3.400 \mathrm{~m}$.a., o que a situa entre as rochas mais antigas da crosta terrestre, Hurley et al., 1973 e Torres, 1975, podendo ser cronologicamente correlacionável com a Série Onverwacht da Rodésia.

Bellizzia (1972), reconheceu vários núcleos granulíticos de idade arqueana na América do Sul: Imataca (Venezuela), Kanuku (Guiana), Adampada - Falawatra (Suriname), e Falsino (Brasil), os quais relacionou com os complexos africanos de Kenema (Sierra Leone) e Man-sasca (Libéria). Essa autora distingue dois episódios tectonomagmáticos maiores no Arqueano: Guriense ( $3.000-3.400$ m.a.) e Aroensis $(2.750-2.650 \mathrm{~m} . \mathrm{a}$.$) , relacionando$ os núcleos granulíticos ao primeiro, e os cinturōes anfibolíticos ao segundo. Observando-se o quadro de correlações que acompanha o trabalho de Bellizzia (1972), percebe-se que o grau de matamorfismo foi um dos critérios utilizados no estabelecimento do limite Proterozóico/Arqueano, pois as faixas de fáceis xisto-verde são situadas no Proterozóico Inferior e as unidades de fáceis anfibolito, são relatadas ao Arqueano Superior.
Além do grau de metamorfismo e de valores radiogênicos, parâmetros petroquímicos podem ser de grande valia para a separação Arqueano/Proterozóico Inferior. Um desses elementos é o índice petrogenéoico $\left(\mathrm{K}_{2} \mathrm{O} / \mathrm{Na}_{2} \mathrm{O}\right)$, cujos valores são geralmente inferiores a 1 em rochas ígneas e metamórficas arqueanas, sendo normalmente superiores a 1 (entre $1 \mathrm{e}$ 3) nos complexos do Proterozóico Inferior. Esse fato é assinalado por Engel et al. (1974), estando diretamente relacionado com a evolução crustal.

McConnell \& Williams (1970) admitem a existência de duas unidades de idade arqueana na Guiana. Na província geológica do sul, os gnaisses de alto grau de metamorfismo e os piroxênio-granulitos do tipo charnockítico que compõem o Grupo Kanuku, são considerados de idade pré-transamazônica. $\mathrm{Na}$ tabela de correlações que acompanha o trabalho desses autores, o Granito Makarapan, na província do norte, também é posicionado no Arqueano. Sugerem ainda que grandes áreas situadas nas bacias dos altos cursos dos rios Essequibo e Corentyne (SE da Guiana), ...."representam essencialmente embasamento arqueano, embora tenham sido localmente reativados e remobilizados durante a orogenia de $2.000 \mathrm{~m}$.a., e também, em áreas restritas, pelo episódio tectono-termal datado de $1.300-$ 1.200 m.a. e denominado K'Mudku Milonitic Episode por Barron (1966)".

Determinações de idade executadas em minerais resistatos como rutilo e zirconita, por Choubert (1964), comprovam que boa parte do pré-Cambriano da Guiana Francesa pode ser situado no Arqueano. Este é o caso da Série Ille de Cayenne. definida por esse mesmo autor em 1965, como constituída principalmente por anfibolitos, paragnaisses, quartzitos, quartzo-dioritos e granodioritos.

$\mathrm{Na}$ região norte brasileira, o Arqueano é coberto por rochas metamórficas representativas do ciclo Transamazônico, o qual tem seu desenvolvimento situado no intervalo de tempo de $2.600 \mathrm{~m}$.a. a $1.900 \mathrm{~m}$.a. As seqüências litológicas oriundas desse ciclo, entre as quais os exemplos melhor conhecidos até o presente são os Grupos Vila Nova e Grão Pa- 


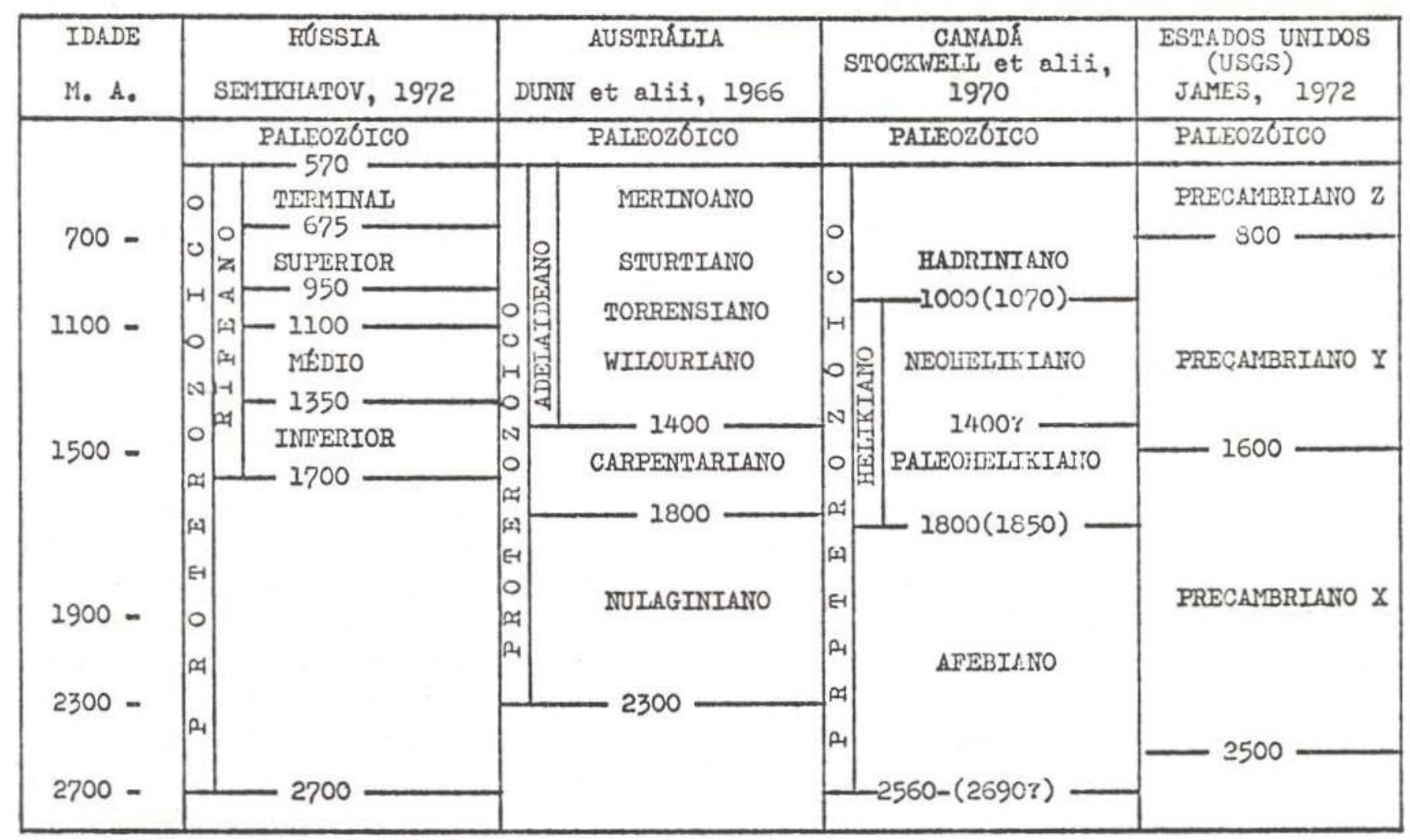

QUADRO II - Comparaçöes de escalas geocronológicas do Pré-Cambriano Superior (Proterozóico) Extraido de Semikhatov, M. A. (1973)

rá e os menos estudados os Grupos Cauarane e Tunuí, sabidamente não atingiram os fáceis almandina-anfibolito e granulito. Além disso, até o presente não se conhecem eventos de migmatização e granitização associados à orogenia Transamazônica. Desse modo, parece ser válido, no atual estágio de conhecimentos, relacionar as rochas desses fáceis ao Arqueano, como seria o caso dos granulitos do rio Falsino, no Amapá (Costa, 1974); os anfibolitos, charnockitos e dioritos do Grupo Moura, na região do rio Negro (Santos et al., 1974); os charnoquitos, hornblenda-gnaisses, anfibolitos, hornblenditos e migmatitos inclusos na "Associação Rupununi", no Território de Roraima (Bomfim et al., 1974). Nessa última região, duas datações disponíveis para a Associação Rupununi, pelo método $\mathrm{K} / \mathrm{Ar}$, são mencionadas por Maridetta (1970): 2.527 e 4.400 m.a., sendo a primeira em hornblenda-gnaisse e a última em anfibolito.
No Estado do Amazonas e Sudeste de Roraima as faixas metamórficas vem sendo englobadas no Grupo Anauá (denominação criada por Ramgrab \& Damiăo, 1970), sendo disponível uma determinaçăo de idade pelo método $\mathrm{K} / \mathrm{Ar}$ correspondente a $2.800 \pm 120 \mathrm{~m}$.a. (Araújo Neto \& Moreira, 1976).

Os antigos núcleos arqueanos têm considerável distribuição na região sudoeste do $\mathrm{Pa}$ rá e sudeste do Amazonas, onde foram definidos por Pessoa et al. (1977) como constituindo o Grupo Cuiú-Cuiú (atualmente Suíte Metamórfica Cuiú-Cuiú). Estes metamorfitos encerram as rochas matrizes do ouro da regiäo, a qual representa a principal província aurifera do país.

A distribuição das principais faixas metamórficas arqueanas na Plataforma Amazônica está esquematizada na Figura 1, havendo possibilidade de que outros núcleos sejam delimi- 
tados no futuro, nas áreas menos conhecidas. especialmente no Alto rio Negro.

\section{PROTEROZÓICO INFERIOR}

O Proterozóico Inferior abrange as rochas cujas idades correspondem ao Ciclo Orogênico Transamazônico, nome adotado por Hurley et al. (1968) e atualmente incorporado na literatura geológica da região. Esses autores apresentaram resultados radiométricos de análises de rochas coletadas na Amazônia Oriental, situando a principal fase dessa orogenia em torno de 2.000 m.a., a qual correlacionaram com rochas do cráton Congolês no Gabão.

No Brasil, os representantes mais característicos e conhecidos dessa orogênese, são os Grupos Grão Pará e Vila Nova, sendo provável que o Grupo Tunuí (Pinheiro et al., 1977), pelo seu posicionamento estratigráfico, fácies de metamorfismo e estilo de dobramento, possa ter se originado durante o evento Transamazônico. Igualmente, o Grupo Cauarane do extremo noroeste de Roraima, proposto por Montalvão et al. (1975b), constituindo uma faixa disposta segundo NW/SE e metamorfisado no fáceis xistos-verdes a anfibolito, pode ser correlato aos metamorfitos transamazônicos.

O primeiro, aflorante no setor centro-sul do Estado do Pará, constituído pela Seqüência Paleovulcânica Inferior, Formação Carajás e Seqüência Paleovulcânica Superior - Beisiegel et al. (1973) - teve a idade de suas rochas básicas determinadas por Silva et al. (1974), os quais encontraram um valor de $2.000 \mathrm{~m}$.a. Esse grupo foi dobrado e metamorfisado no fácies xistos-verdes a anfibolito, tendo as determinações de idade em suas rochas revelado os mesmos valores encontrados no embasamento polimetamórfico sobre o qual repousa (Silva et al., 1974). Tal fato indica que nessa região as rochas arqueanas, durante a orogênese Transamazônica, foram pelo menos em parte remobilizadas, tendo sido afetadas pelos efeitos térmicos desse diastrofismo, fenômeno responsável pelos valores radiométricos pós-cristalinos detectados.

No Território do Amapá, os metamorfitos do Grupo Vila Nova, constituídos principal- mente por actinolita-xistos, muscovita-quartzitos, talco-xistos e itabirito (Costa et al., 1974), foram metamorfisados no fácies xisto-verde e anfibolito (Lima et al., 1974). Estes últimos, a partir de determinaçōes pelo método $\mathrm{Rb} / \mathrm{Sr}$, executadas por Hurley et al. (1968) em xistos e anfibolitos, construiram uma isócrona de $2.090 \mathrm{~m}$.a. Observa-se, portanto, que tanto no seu posicionamento cronoestratigráfico, como no seu fácies metamórfico, os Grupos Pará e Vila Nova são perfeitamente correlacionáveis. Ademais, a análise das imagens radargramétricas permite observar o mesmo estilo de dobramento para as duas unidades, além de um certo paralelismo entre os sinclinórios de $\mathrm{Ca}$ rajás e da serra do Navio. ( $\left.N 50^{\circ}-70^{\circ} \mathrm{W}\right)$. Este fato é importante porque indica que a evolução geológica dessas duas áreas, pelo menos até o fim do Proterozóico Inferior, foi muito semelhante, tendo se comportado provavelmente como um único bloco.

Os metassedimentos da região do Alto rio Negro, que constituem as serras de Tunuí, Traíra e Caparro, foram denominados de Formação Tunuí por Montalvão et al. (1975a), sendo compostas essencialmente por quartzitos. As análises petrográficas de muscovita-quartzitos e quartzitos dessa área, descritos por Achão \& Salas (1974), indicam um fácies metamórfico de epizona e mesozona, ou sej̣a xistos verdes e anfibolito. Embora as informações dessa unidade sejam exíguas, a partir de seu grau de metamorfismo, padrão de dobramentos e posicionamento estratigráfico (mais antigo que a Formação Roraima), pode-se situá-la preliminarmente no Ciclo Transamazônico.

Na Guiana, de acordo com McConnell \& Williams (1970), o Proterozóico Inferior é constituído por três tipos de assembléias: geossinclinal, de prataforma e subcontinental, relacionadas com dobramentos, metamorfismo, anatexia e individualização de granitos sintectônicos e pós-orogênicos. Tais seqüências, metamorfisadas no fácies xistos verdes e com idade em torno de $1.800-2.000 \mathrm{~m}$.a., representam um episódio tectono-termal que inicialmente foi denominado de Akawaian Williams et al. (1967) - e que atualmente é 
incluído no Ciclo Orogênico Transamazônico. Representativos desse evento são os Grupos Barama (metassedimentos pelíticos, lavas e piroclásticas metamorfisadas, gonditos e filito) e Mazaruni (metarenitos e grauvaques intercalados com metavulcânicas e sedimentos pelíticos), ocorrentes no norte da Guiana. Os autores incluem ainda no ciclo Transamazônico, como fácies de plataforma, a Formação Iwokrama e as unidades correspondentes aflorantes nos países vizinhos (Brasil, Venezuela e Suriname).

Ainda segundo McConnell \& Williams (1970), a Assembléia Barama-Mazaruni estende-se à Venezuela, onde foi definida como Assembléia Pastora-Carichapo por Kalliokoski (1965).

Relatam ainda que as Assembléias Barama-Mazaruni e Pastora-Carichapo constituem uma faixa geossinclinal alongada segundo WNW/ESE. Percebe-se portanto, que além do fácies metamórfico semelhante e da presença de gonditos, o Grupo Vila Nova e as Assembléias geossinclinais do Proterozóico Inferior da Guiana e Venezuela, mostram certa concordância estrutural. Entretanto, os metamorfitos dos Grupos Vila Nova e Grão Pará parecem corresponder apenas à seção inferior do ciclo Transamazônico na Guiana (Grupo Barama), na Venezuela (Grupo Pastora), em Suriname (Formação Paramaca) e na Guiana Francesa (Série Paramaca), sendo desconhecidos no Brasil, até o presente, depósitos clásticos correlacionáveis aos Grupos Mazaruni e Carichapo, os quais representam o fechamento do ciclo Transamazônico.

A existência de representantes do ciclo Transamazônico em diversas regiōes da Amazônia, tanto ao norte como ao sul da bacia sedimentar paleozóica, sugere que no Proterozóico Inferior os chamados Escudos ou Crátons das Guianas e do Guaporé (ou Brasil-Central) constituíam uma única faixa orogenética, um dos diversos motivos pelos quais prefere-se empregar o termo Plataforma Amazônica em detrimento de Cráton Guaporé e das Guianas.

De acord̄o com a idade admitida e os valores geocronológicos obtidos para os representantes do ciclo Transamazônico, observa- -se, no Hemisfério Norte, a quase total ausência de grandes eventos orogênicos com os quais possa ser aquele ciclo correlacionado (Quaciro I). Apenas o Complexo Stranovoi, no Escudo Aldan, situa-se no intervalo de tempo em torno de $2.000 \mathrm{~m}$.a. No Hemisfério Sul, ao contrárío, o ciclo Transamazônico encontra eventos, senão correspondentes, pelos menos correlacionáveis, nas áreas cratogênicas da África e da Austrália. Correlações com o Eburneano, da África Ocidental, foram estabelecidas por Hurley et al. (1968). Semelhante comparação é feita por McConnell \& Williams (1970), por Bellizzia (1972) e por McConnell (1972), o qual relata que o ciclo Orogênico Transamazônico é um " ... episódio que parece corresponder estreitamente com o Episódio Eburneano da África Ocidental e com o Ubendiano, da África Oriental e Meridional", os quais situam-se em torno de $2.000 \mathrm{~m}$.a. Tais valores, por sua vez guardam certa relação com o Nullaginiano, na Austrália, cuja idade situa-se no intervalo de 1.800 a 2.300 m.a. (Dunn et al., 1966).

Alguns autores incluem no ciclo Transamazônico rochas vulcânicas e intrusōes graníticas associadas, para as quais Priem et al. (1971) estabeleceram uma isócrona de $1.810 \pm 40$ m.a., relacionando-as com o "Magmatismo Ácido Transamazônico". Todavia, algumas restrições podem ser feitas a esse procedimento, como segue:

As principais subdivisões do Pré-Cambriano (Semikhatov, 1974), têm seus limites determinados pelo encerramento de épocas de dobramento, associadas com inconformidades de caráter regional. A denominação Transamazônico, foi criada por Hurley et al. (1968), para definir um ciclo orogênico de grande extensão na América do Sul, com idades principais em torno de $2.000 \mathrm{~m}$. a. Ultimamente, o paroxismo dessa orogênese é tido como situado há $\pm 2.200 \mathrm{~m}$.a. Como o paroxismo do Magmatismo Uatumã transcorreu há \pm 1.800 m.a., observa-se que há uma defasagem de tempo de $\pm 400 \mathrm{~m}$.a. entre os dois eventos.

O caráter anorogênico do magmatismo ácido Uatumã tem sido assinalado por diversos autores, sendo enfatizado por Issler (1974). 
No Brasil, o vulcanismo desse evento (Surumu, Iriri), foi seguido de intrusōes graníticas (Saracura, Maloquinha, Seringa, Mapuera, etc.) e intensa sedimentação (Roraima, Gorotire, Cubencı anquém). Provavelmente, a subsidência, associada a falhamentos gravitacionais. que possibilitou essa possante sedimentação, representa o fechamento desse evento anorogênico, pois entre os sedimentos ocorrem camadas de tufos ácidos, representantes da ressurgência do magmatismo ácido. Tanto ao norte (Território de Roraima), como ao sul (região dos rios Aripuanã, Sucunduri e Tapajós), as vulcânias inferiores, mostram concordância regional com os sedimentos, havendo entre as duas unidades uma discordância regional erosiva, não angular, esta podendo ser observada apenas em escala local. A discordância entre o magmatismo anorogênico e a orogênese Transamazônica, ao contrário, é sem dúvida a inconformidade mais notável existente neste setor da América do Sul, devendo-se pressupor a instalação de longo período erosivo ao término da Orogênese Transamazônica, antecedendo o inicio do magmatismo Uatumä, o qual pode ter alcançado $400 \mathrm{~m}$.a. Dessa forma, baseado nas distinçōes existentes, admite-se que o limite entre - Proterozóico Médio e Inferior, deva ser colocado entre as rochas da orogênese Transamazônica e os representantes do magmatismo ácido anorogênico Uatumã e não entre esse último evento e a cobertura sedimentar de plataforma. Assim, sugere-se que o valor numérico de $1.800 \mathrm{~m}$.a. correntemente adotado para o limiar Proterozóico Médio-/Inferior, seja rebaixado para $1.900 \mathrm{~m} . \mathrm{a}$. , possibilitando, desse modo, a inclusão dos representantes mais antigos da anorogenia ácida, çom idades situadas entre 1.800 e $1.900 \mathrm{~m}$.a. Esse último valor, portanto, identifica a linde entre dois episódios de amplitude continental, um orogênico e outro anorogênico. Tal idade (1.900 \pm $200 \mathrm{~m}$.a.) foi empregada por Clifford (1967) para estabelecer o limite entre o Ubendiano (Proterozóico Inferior) e o Limpopoano (Proterozóico Médio), na região sul da Africa. Almeida (1974) posicionou o ciclo Transamazônico no intervalo $1.850 \pm 50 \mathrm{~m} . \mathrm{a} . - \pm 2.600$ m.a., sendo comparado cronologicamente com o ciclo Suecofeniano/Kareliano do Escu- do Báltico, tendo excluído o Grupo Uatumã desse evento, o qual considerou pós-Transamazônico. Todavia, esse autor considera o Grupo Grão Pará (orogênico e metamórfico) posterior àquele ciclo, correlacionando-o com a Formação Rio Fresco embora, segundo Silva et al. (1974), exista uma inconformidade en. tre as duas unidades. Entretanto, a cobertura sedimentar existente sobre o Grupo Grão Pará, não tem sido correlacionada com a Formação Rio Fresco, como fizeram Silva et al. (1974), e sim com a Formação Gorotire (Amaral, 1970; Beisiegel et al., 1973). Na verdade, a partir da hipótese de Almeida, F.F.M. de (1974), há possibilidade de que tal cobertura não represente nenhuma dessas duas formações, e sim, uma terceira unidade a qual seria correspondente às coberturas psamíticas que fecharam o ciclo Transamazônico na Guiana (Grupo Mazaruni) e na Venezuela (Grupo Carichapo).

Além disso, é interessante observar que as características do Suecofeniano/Kareliano descritas por Almeida (1974) são sensivelmente similares àquelas inerentes ao Grupo Grão Pará, entre as quais destacam-se “... Os complexos do Suecofeniano/Kareliano constituem-se de grande variedade de matassedimentos detríticos e químicos (minério de ferro) associados à metavulcânicas". Dobramentos orogênicos e metamorfismo no fáceis xisto verde a anfibolito.

\section{PRoterozóICo MÉDIo}

Desde há $1.900 \mathrm{~m}$.a. não se tem registro de atividade orogênica na Plataforma Amazônica, sendo esse período de evolução crustal representado por unidades resultantes de um ciclo anorogênico, caracterizado pela sucessão de diversos e razoavelmente definidos episódios continentais. Como foi abordado no capítulo anterior, o início do Proterozóico Médio identifica-se com as primeiras manifestações de um paroxismo vulcano-plutônico, de composição eminentemente ácida, o' qual ocupa, - descontinuamente, área superior a $1.500 .000 \mathrm{~km}^{2}$. O vulcanismo, no Amazonas, Pará e norte de Mato Grosso, faz parte do Grupo Uatumã, sendo composto principalmente 


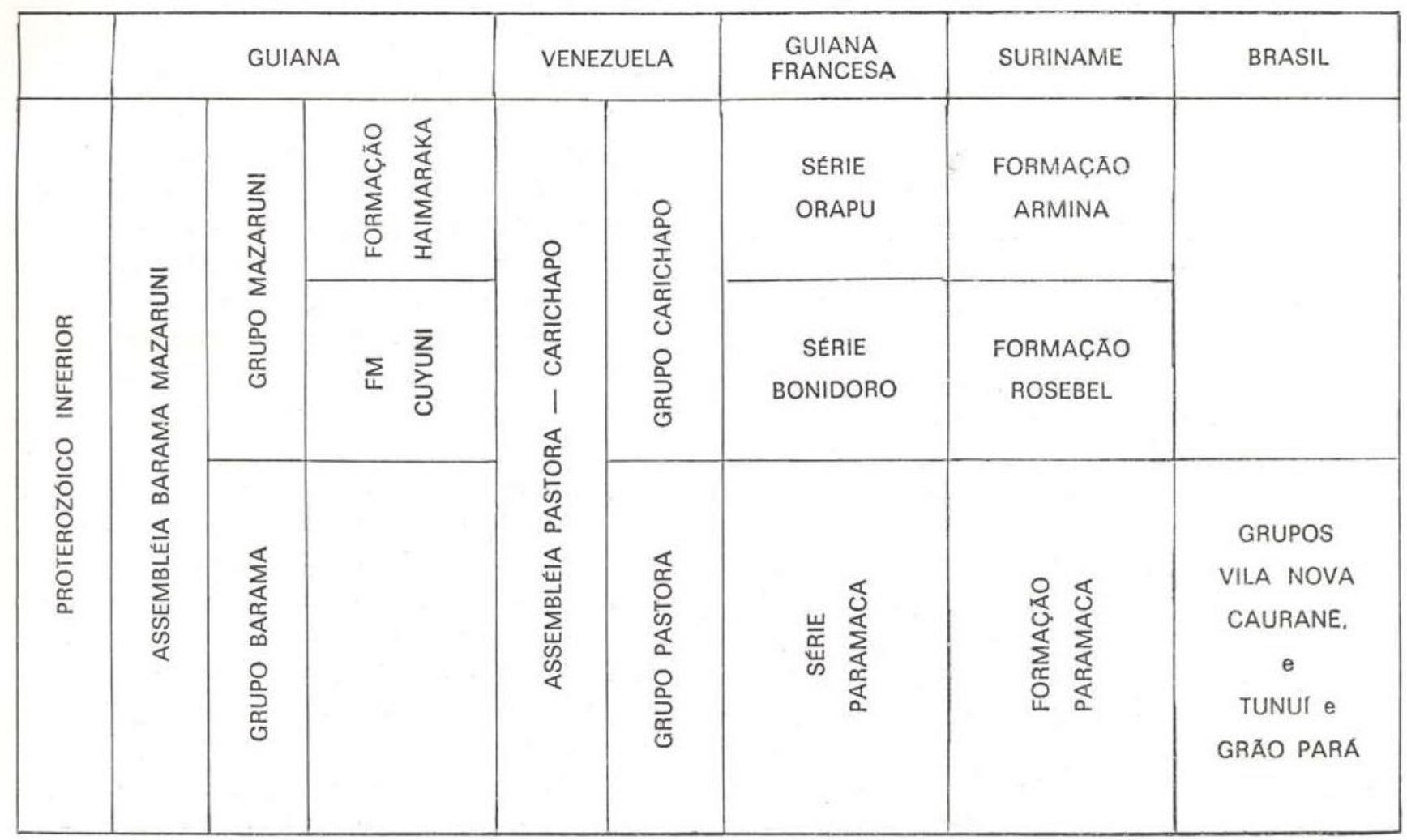

QUADRO III - Correlações no Proterozóico Inferior

por riodacitos, riolitos, dacitos, tufos, brechas vulcânicas, andesitos, etc. No Amazonas, conforme Liberatore et al. (1972) — região sudeste - e Santos et al. (1974) - região nordeste - predominam amplamente riodacitos e riolitos. No Pará, na região Tapajós-Jamanxim, predominam riodacitos e piroclásticas, com riolitos e dacitos secundários e ocorrências de andesitos somente na forma de diques (informações do Projeto Jamanxim, Convênio DNPM/CPRM). Derrames de andesitos, ainda sem preponderar sobre as vulcânicas ácidas, são descritos por Geomineração Ltda. (1971), nos rios Trombetas e Maecuru. Razoável distribuição de andesitos é assinalada por Silva et al. (1974) na região do rio Fresco, os quais foram denominados Formação Sobreiro. No Território de Roraima, esse vulcanismo é designado Formação Surumu, e na região de Tumucumaque como Formação Iricoumé, sendo caracterizado essencialmente por riodacitos, com dacitos; tufos e riolitos subordinados. A faixa vulcânica Surumu, de desenvolvimento WNW/ESE, extende-se à Venezuela, Guiana e
Suriname. No primeiro caso. é conhecida, na região limítrofe com o Brasil, juntamente com os granitos associados, como Grupo Pakaraima (Bellizzia \& Martin-Bellizzia, apud Bellizzia, 1972). A mesma unidade, na região do alto Orinoco é denominada de Grupo Cuchivero, por Bellizzia (1972), composta por riolitos, riodacitos, quartzo-latitos, dacitos e equivalentes piroclásticos associados. Tanto o Grupo Pakaraima, como o Grupo Cuchivero, säo posicionados por Bellizzia (1972) no intervalo de 1.800 a $2.000 \mathrm{~m}$.a.

Na Guiana, vários eventos vulcanogênicos ácidos são relatadcs ao Proterozóico Médio, identificados pelo Grupo Kuyuwini (sul da Guiana, associado com granitos) e, o Grupo Burro-Burro (região central, também associado com intrusões ácidas). Ao primeiro, Berrangé (1973) atribui, baseado em determinações radiométricas, idade de $1.814 \pm 64$ m.a. (Rb/Sr). O mesmo autor cita uma isócrona de $1.915 \pm 80 \mathrm{~m}$.a. para o Grupo Burro-Burro (K/Ar). 
No Suriname, à Assembléia Granítico-Vulcânica é admitida uma idade de $1.810 \pm 40$ $\mathrm{m} . \mathrm{a}$., de acordo com isócrona $\mathrm{Rb} / \mathrm{Sr}$ obtida por Priem et al. (1971). Anteriormente, esses autores determinaram a idade da Formação Dalbana (principalmente riolitos), hoje inclusa naquela "Assembléia", obtendo um valor de $1.819 \pm 15$ m.a., Priem et al., (1971).

No Brasil, em Roraima, a Formação Surumu foi datada por Amaral (1970), pelo método $\mathrm{K} / \mathrm{Ar}$, o qual obteve valores oscilando entre $1.069 \pm 15 \mathrm{~m}$.a. e $1.283 \pm 54 \mathrm{~m}$. a. Esse fato levou esse autor a considerar o vulcanismo ácido mais jovem que a Formação Roraima, considerada então mais antiga que $1.600 \mathrm{~m} . \mathrm{a}$.

Posteriormente, Amaral (1974), obteve uma isócrona, a partir das rochas vulcânicas da Formação Surumu, a qual forneceu um valor de $1.580 \pm 23 \mathrm{~m}$.a., levando-o novamente a contestar a idade da Formação Roraima.

Nessa região, ultimamente, dispõe-se de duas determinações, executadas pelo projeto RADAM, pelo método $\mathrm{Rb} / \mathrm{Sr}$, as quais indicam $1.875 \pm 52 \mathrm{~m}$.a. para uma amostra de riolito e $1.740 \pm 40 \mathrm{~m}$.a. para um dacito cataclástico. Montalvão et al. (1975a) registraram uma isócrona de $\pm 1.890 \mathrm{~m}$.a. para a Formação Surumu.

No Amazonas e no Pará, os valores obtidos até poucos anos atrás, pelo método $\mathrm{K} / \mathrm{Ar}$, na datação do vulcanismo Uatumã, invariavelmente não ultrapassaram $1.200 \mathrm{~m}$.a. Ultimamente, através do método $\mathrm{Rb} / \mathrm{Sr}$, Amaral (1974) relata duas determinaçōes disponiveis para a região Tapajós-Jamanxim, com 1.712 m.a. Na bacia do rio Fresco, o valor obtido por esse autor foi de $1.690 \pm 31 \mathrm{~m}$.a.

Diversas determinações radiométricas executadas por Santos et al. (1975) na regiăo da folha Tapajós (SB.21), permitiram a construção de uma isócrona para as vulcânicas ácidas do Grupo Uatumã (Formação Iriri), com um valor de $1.700 \mathrm{~m}$.a. Para a região ao norte da bacia paleozóica, Montalvão (1975) assinalou uma isócrona de $1.836 \pm 35 \mathrm{~m}$.a. para as vulcânicas e intrusivas associadas.

$\mathrm{Na}$ região do rio Xingu, na folha Araguaia (SB.22) - Basei (1973), apud Silva et al.
(1974), montou uma isócrona para os vulcanitos ácidos do Grupo Uatumã, encontrando o valor de $1.693 \pm 21 \mathrm{~m}$.a.

Comparando-se os valores acima, obtidos para o vulcanismo ácido a partir de 1973 pelo Projeto RADAM e por Amaral (1974), na regiăo do Amazonas e Pará (Grupo Uatumã), com aqueles oriundos de Roraima (Formação Surumu), Venezuela (Grupos Pacaraima e Cuchivero), Guiana (Grupos Burro-Burro e Kuyuwini) e Suriname (Formação Dalbana), observa-se que os primeiros oscilam em torno de 1.700 $\mathrm{m}$.a. e os últimos em volta de $1.810-1.900$ $\mathrm{m} . \mathrm{a}$. Desde que os valores radiométricos estejam corretos, pode-se pressupor uma migração dos espasmos vulcânicos desde o norte com direção ao sul, com uma defasagem de tempo aproximada de $110-200 \mathrm{~m}$.a.

$\mathrm{Em}$ todas as regiöes, acima assinaladas, de ocorrências de representantes desse vulcanismo ácido, associam-se-lhes corpos intrusivos anorogênicos, cujas idades, mais jovens, pouco diferem daquelas das vulcânicas associadas. Na sua maioria, são constituídos por granitos, muitos dos quais de caráter alcalino e secundariamente por rochas alcalinas dominantemente sieniticas. Tais intrusōes podem ser agrupadas em duas categorias, de acordo com o seu relacionamento estratigráfico e cronologia: aquelas que afetam os vulcanitos, sendo anteriores à cobertura sedimentar pós-Uatumã e aquelas mais jovens que essa sedimentação de plataforma. Na maior parte enquadram-se no primeiro grupo, tendo sido registradas principalmente pelo Projeto RADAM, tanto ao norte, como ao sul da bacia Amazônica, destacando-se os Granitos Maloquinha (Tapajós - SB.21), Velho Guilherme (Xingu - SB.22), Mapuera (Mapuera NA.21), Mel (Roraima - NA.20) e Falsino (Amapá - NA.22) e os sienitos Erepecuru (Erepecuru - NA.21), Mapari (Amapá NA.22). Ultimamente, a CPRM tem assinalado intrusōes ácidas do Grupo Uatumā em di. versas regiōes, como Roraima (Granitos Saracura e Guariba), Amazonas (Granito Abonari) e Pará (Granitos Porquinho), sendo os primeiros conhecidos desde Ramgrab et al. (1972). Provavelmente, o riebéckita - granito do rio Guariba e os diques de micronordma- 
kito do rio Sucunduri (sudeste do Amazonas), descritos por Liberatore et al. (1972) situam-se nesse mesmo evento.

A existência de representantes do magmatismo Uatumã, tanto ao norte como ao sul da bacia paleozóica, indica que pelo menos desde o início do Proterozóico Médio, os Escudos das Guianas e Brasil Central têm se comportado como um único bloco cratonizado.

De um modo geral, os eventos a grosso modo cronologicamente correspondentes à anorogenia Uatumã, ocorridos no Hemisfério Norte, foram de caráter orogênico. No Escudo Canadense, o episódio Hudsoniano 11.700 \pm 150 m.a.), na Groenlândia, o Ketilidiano (1.790 - 1.600 m.a.), no Escudo Ucraniano, o Voliniano (1.700 $\pm 100 \mathrm{~m}$.a.), no Escudo Báltico, o Suecofeniano $(1.700-2.000$ m.a. $)$ e na Plataforma Siberiana, o Jotniano $(1.700$ m.a.), são representativos de tais eventos do Proterozóico Médio nesse hemisfério.

As considerações de Almeida (1974), correlacionando em idade e natureza o evento Uatumã com o Sub-Jotniano do Escudo Báltico (pós-Jatuliano) são de grande importância, pois sugerem que manifestações magmáticas de caráter anorogênico, durante o Proterozóico Médio, não foram restritas à Plataforma Amazônica, tendo afetado outros continentes.

É interessante notar que o bloco anorogênico Uatumã está limitado, tanto a leste como aparentemente a oeste, por importantes lineamentos de direção aproximada NNW/SSE. A leste, não ocorrem representantes vulcânicos desse magmatismo no Amapá, bem como no setor oriental do Estado do Pará, ou seja, a lešte dos rios Jari e Araguaia. Esse fato explicaria a ausência de rochas similares no setor ocidental da África, pois a expansão do Grupo Uatumã em direção ao leste foi interrompida pela faixa orogênica Paraguai-Araguaia.

O limite oeste, embora menos conhecido no presente, situa-se aproximadamente paralelo ao chamado alto de Purus, não havendo registro, a oeste dessa estrutura, de rochas relacionadas ao evento Uatumã, tanto na região do Alto rio Negro, como em Rondônia.
Com 0 encerramento da fase vulcano-plutônica, instalou-se um período erosivo, não muito prolongado, seguido de subsidência e intensa sedimentação clástica em ambiente predominantemente continental (Formações Roraima e Gorotire), localmente marinho (Grupo Beneficente). Durante essa deposição ocorreu uma ressurgência do magmatismo ácido, manifestada pela intercalação de tufos ácidos, ocasionalmente derrames ácidos, no pacote sedimentar. Exemplos clássicos desse evento são o Membro Tafelberg de Priem et al. (1973) no Suriname, o Membro Médio de Bomfim et al. (1974) em Roraima, a Suqüência Vulcano-Sedimentar de Liberatore et al. (1972) no sudeste do Amazonas e os tufos da braquissinclinal do rio Pitinga (Mandetta et al., 1974), no nordeste do Amazonas. No Suriname, Priem et al. (1973), através da construção de uma isócrona, atribuem uma idade de $1.599 \pm 18$ m.a. a essas piroclásticas. Dessa forma, esse evento explosivo seria sincrônico do chamado Granito Surucucu do noroeste de Roraima, cuja idade, conforme Montalvão et al. (1975), situa-se no intervalo $1.500-1.600 \mathrm{~m}$.a. Relacionamento intrusivo desse evento foi descrito por Reid (1972) na Venezuela, onde verificou uma intrusão granítica na Formação Roraima. Tal manifestação ígnea corresponde ao episódio Parguazense de Bellizzia (1972), cujos representantes na Venezuela identificam-se com Granitos Rapakivi de Parguaza, nos quais Mendonza et al. (1975) descrevem xenólitos de rochas sedimentares, riolitos, metagabros, granitos, anortositos, etc. Esses autores assinalam duas datações para esse magmatismo, uma obtida em isócrona por rocha total $(\mathrm{Rb} / \mathrm{Sr})-1 .-90 \mathrm{~m}$.a. e outra pelo método $\mathrm{U} / \mathrm{Pb}-1.600 \mathrm{~m} . \mathrm{a}$.

É interessante notar que, se esse episódio for sincrônico ao episódio Tafelberg de Priem et al. (1973), os granitos tipo Parguaza devem afetar somente a seção inferior a média da cobertura sedimentar, de modo que teriam uma idade ligeiramente mais antiga que o. chamado Vulcanismo Roraima (Avanavero). Entretanto, os "sills" e diques desse evento básico, durante muito tempo revelaram idades sensivelmente mais antigas que os tufos ácidos e intrusões associadas. Snelling \& 


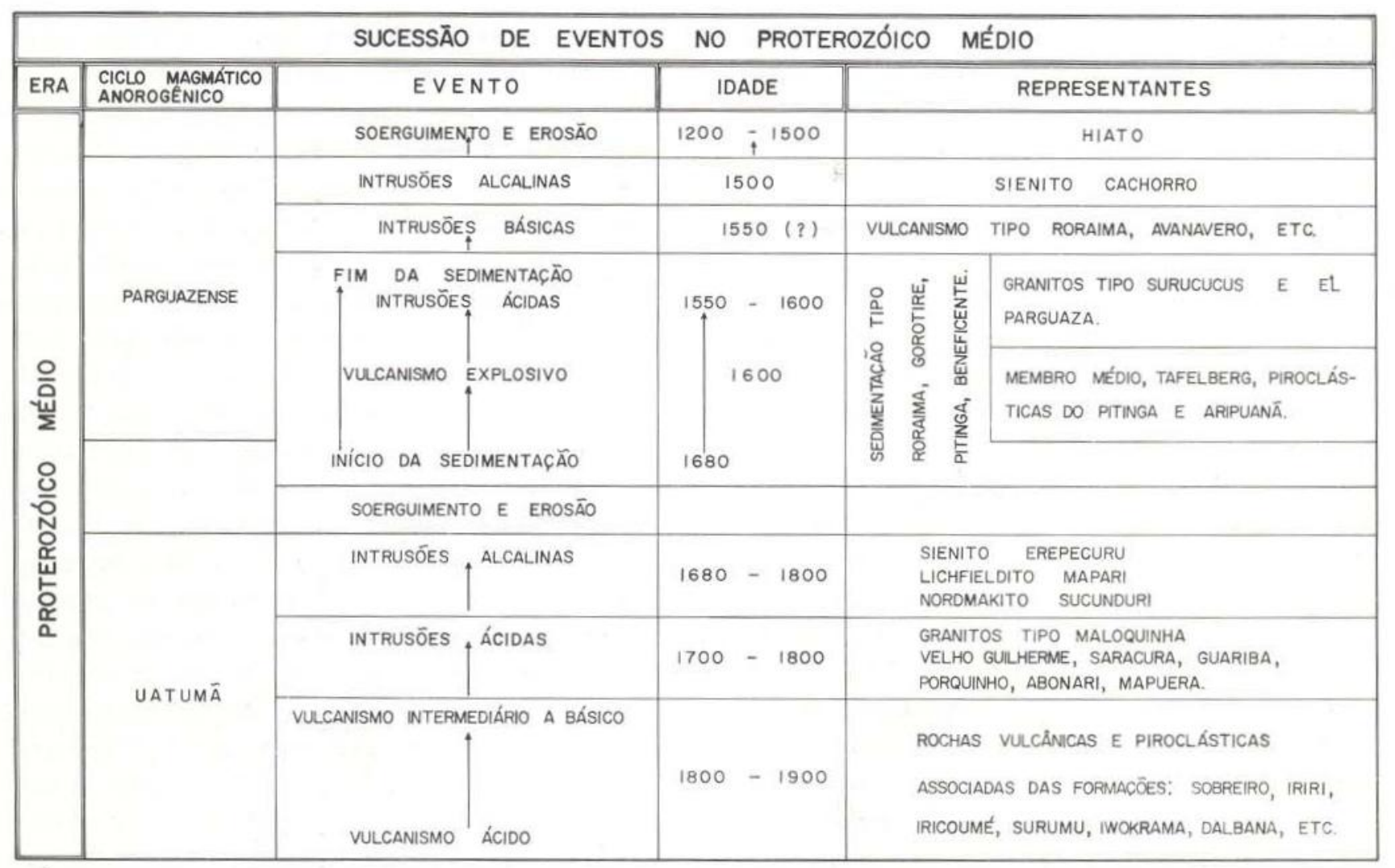

\section{QUADRO IV}

McConnell (1969) apresentaram duas isócronas, uma para os "sills" de diabásio $1.695 \pm 66 \mathrm{~m} . \mathrm{a}$. - e outra para o hornfel da zona de contato $-1.640 \pm 30 \mathrm{~m}$.a. Todavia, Hebeda et al. (1973) estabeleceram uma idade de $1.603 \pm 27 \mathrm{~m}$.a. para o dolerito Avanavero do Suriname, tendo demonstrado a existência nessas rochas de argônio em excesso, responsável pelas idades mais avançadas obtidas em trabalhos precedentes.

Imediatamente após o magmatismo básico, nova reativação da plataforma proporcionou a incidência de novo evento alcalino, provavelmente originado a partir de núcleos ou bolsões previamente diferenciados do manto e posteriormente injetados com maior ou menor assimilação da crosta siálica. Essa tectogênese envolve o Sienito Cachorro descrito por Montalvão et al. (1975) na região norte do Estado do Pará, sendo intrusivo no Granito Mapuera. Segundo Issler et al. (1974) o alcali-sienito Mapari teria $1.537 \pm$ m.a., poden- do desse modo ser relacionado com aquele episódio de reativação cratogênica. Resumin do, percebe-se a incidência de duas manifestações alcalinas no Proterozóico Médio, sendo a primeira, mais antiga, associada ao Episódio Uatumã, sendo anterior à cobertura sedimentar de plataforma e, provavelmente, mais jovem que os granitos e granitos alcalinos do Grupo Uatumã, enquanto que o último espasmo alcalino desse período é incluído no Episódio Parguazense. Todavia, uma melhor definição desses dois episódios somente será possivel através da delimitação de um número maior de corpos, da execuçāo de análises químicas, e de mapeamento em escalas iguais ou maiores que 1:100.000.

Generalizadamente, o esquema evolutivo do Proterozóico Médio pode ser visualizado no Quadro IV, sendo constituído por dois ciclos magmáticos maiores: Uatumã e Parguazense, os quais são caracterizados por uma série de eventos associados. Com o fecha- 
mento do ciclo Parguazense, manifestado por um magmaitsmo alcalino ( $\pm 1.500 \mathrm{~m} . \mathrm{a}$.$) , a$ Plataforma Amazônica deve ter permanecido estável, não tendo sido afetada por nenhum evento diastrófico de maior importância tendo provavelmente permanecido, pelos menos na sua maior parte, como área positiva, sujeita à degeneração até o encerramento do Proterozóico Médio. Essa conclusão é fundamentada no fato de que, pelo menos até o presente, não ter sido registrado nenhum representante proterozóico situado no intervalo de \pm 1.200 $a \pm 1.500 \mathrm{~m} . \mathrm{a}$., ou seja de idade pós-Parguazense e pré-K'Mudku, tendo esse lapso de tempo se comportado como verdadeiro hiato na seqüência estratigráfica pré-cambriana.

Embora alguns trabalhos tenham revelado algumas idades radiométricas situadas na faixa $1.200 \pm 1.500 \mathrm{~m}$.a., principalmente na região do Alto rio Negro, é bastante provável que tais valores estejam relacionados com rejuvenescimentos isotópicos, pela atuação do evento K'Mudku em litologias mais antigas que o Proterozóico Superior. Não só amostras dos ciclos Uatumã e Parguazense, mas também do ciclo Transamazônico e, significativamente mesmo rochas mais antigas ainda (préTransamazônico), ocasionalmente revelam idades radiométricas correspondentes, ou um pouco mais antigas que o evento tectono-termal K'Mudku, como será abordado no próximo capítulo.

\section{PROTEROZÓICO SUPERIOR}

O limite entre o Proterozóico Médio e o Superior na Plataforma Amazônica é estabelecido pelo início da instalação de um episódio tectono-termal amplamente reconhecido neste continente, o qual tem recebido diversas denominações regionais. Sua atuação identifica-se com amplas faixas de cataclasitos e milonitos originados por esforços de compressão com caráter continental, os quais afetam em maior ou menor grau grande parte das litologias originadas pelos eventos antecedentes. Esse evễnto foi inicialmente reconhecido na Guiana, sendo denominado por Barron (1966) de K'Mudku Milonite Episode, tendo-lhe atribuído uma idade em torno de $1.200 \mathrm{~m}$.a. e uma origem associada com zonas de movimentos transcorrentes. A perda de estrôncio e argônio radiogênicos de biotitas da "Assembléia vulcano-plutônica" na região do Suriname, foi interpretada por Priem et al. (1971) como o resultado da atuação de um evento tectono-termal pós-Transamazônico, o qual designaram Nickerie Metamorphic Episode, com uma idade situada por volta de $1.200 \pm 100 \mathrm{~m}$.a. Episódio de natureza similar foi descrito por Bellizia (1972) no setor sudeste da Venezuela, o qual foi designado evento Orinoquense, sendo correlacionado com o K'Mudku da Guiana e o Nickerie do Suriname. No Brasil, no setor sudeste da Plataforma Amazônica, no noroeste do Território de Rondônia, o evento responsável pela deformação que afetou a cobertura sedimentar e vulcânica, melhor desenvolvido na região do rio Madeira, foi denominado de Madeirense por Amaral (1974), o qual foi correlacionado em idade aos episódios K'Mudku e Nickerie. Na região nordeste da Plataforma Amazônica, Lima et al. (1974) descreveram uma fase de tectônica ruptural, com rumo $\mathrm{N} 40^{\circ}-60^{\circ} \mathrm{E}$, que se estende por mais de $240 \mathrm{~km}$, desde o rio Jari (Pará) ao rio Falsino (Amapá), a qual afetou o Grupo Vila Nova (Transamazônico) e foi denominado de Episódio Jari-Falsino, tendo igualmente sido correlacionado aos Episódios K'Mudku e Nickerie.

A idade normalmente admitida para esse evento, sob suas mais diversas denominações situa-se por volta de $\pm 1.200 \mathrm{~m}$.a., valor que corresponde ao limite inferior de Almeida (1974) para o Pré-Cambriano Superior. Essa idade reflete períodos de intensa movimentação registrados em outros continentes, representando provavelmente uma época de diastrofismo de âmbito mundial. Correlações do Episódio K'Mudku ou Orinoquense já haviam sido estabelecidas por McConnell (1972) e Bellizzia (1972) com o Kibarano da Africa. Sua época de manifestações e comparável com o Dalslandiano do Escudo Báltico (Burwash, 1969), com o Keweenawan do Canadá e com as rochas alcalinas de Ulkan, no Escudo Aldan da Sibéria. Corresponde, por outro lado à idade estabelecida por Semikhatov (1974) para o topo do Rifeano Médio da Rússia e pa- 
ra o intervalo Helikiano/Hadriniano do Escudo Canadense.

Ao que tudo indica, pelo menos para a porção brasileira da Plataforma Amazônica, o Proterozóico Superior não resume-se apenas na atuação do episódio tectônico acima descrito. Em Rondônia, está razoavelmente definida a existência de um episódio pós-Madeirense, o qual afetou essa região após um período de relativa estabilidade tectônica, quando a reativação de antigos e piofundos falhamentos determinou nova manifestação magmática ácida, definida por Vershure \& Bon (1972) como representativa do Episódio Rondoniense, cuja idade $(980 \pm 20 \mathrm{~m}$.a.) é mais jovem que o Episódio Tectônico Madeirense $( \pm 1.200$ m.a.).

É possivel que o Episódio Rondoniense, em outras regiões da Amazônia esteja repre- sentado por manifestações básicas e/ou alcalinas, já que idades próximas de $1.000 \mathrm{~m}$.a. têm sido determinadas pelo DNPM (tanto pelo RADAM como pela CPRM). É o caso do complexo troctolítico do Projeto Jamanxim-PA, cujas informações de campo indicam ser mais jovem que a cobertura sedimentar de plataforma (pós-Uatumã) e cuja determinação de idade disponivel corresponde ao valor $1.046 \pm$ $20 \mathrm{~m}$.a. (K/Ar).

Além dessa ocorrência, outras províncias básicas do início do Proterozóico ficaram conhecidas há pouco tempo, como o troctolito rio Pardo (1.079 m.a. - Araújo Neto \& Moreira, 1976) e os derrames de Lábrea-AM (1.050 a 1.232 m.a.) e Pacaás Novos-RO (967 a 1.098 m.a.) - Teixeira \& Tassinari (1976). A respeito desse magmatismo, com suas diversas ocorrências perfeitamente cor-

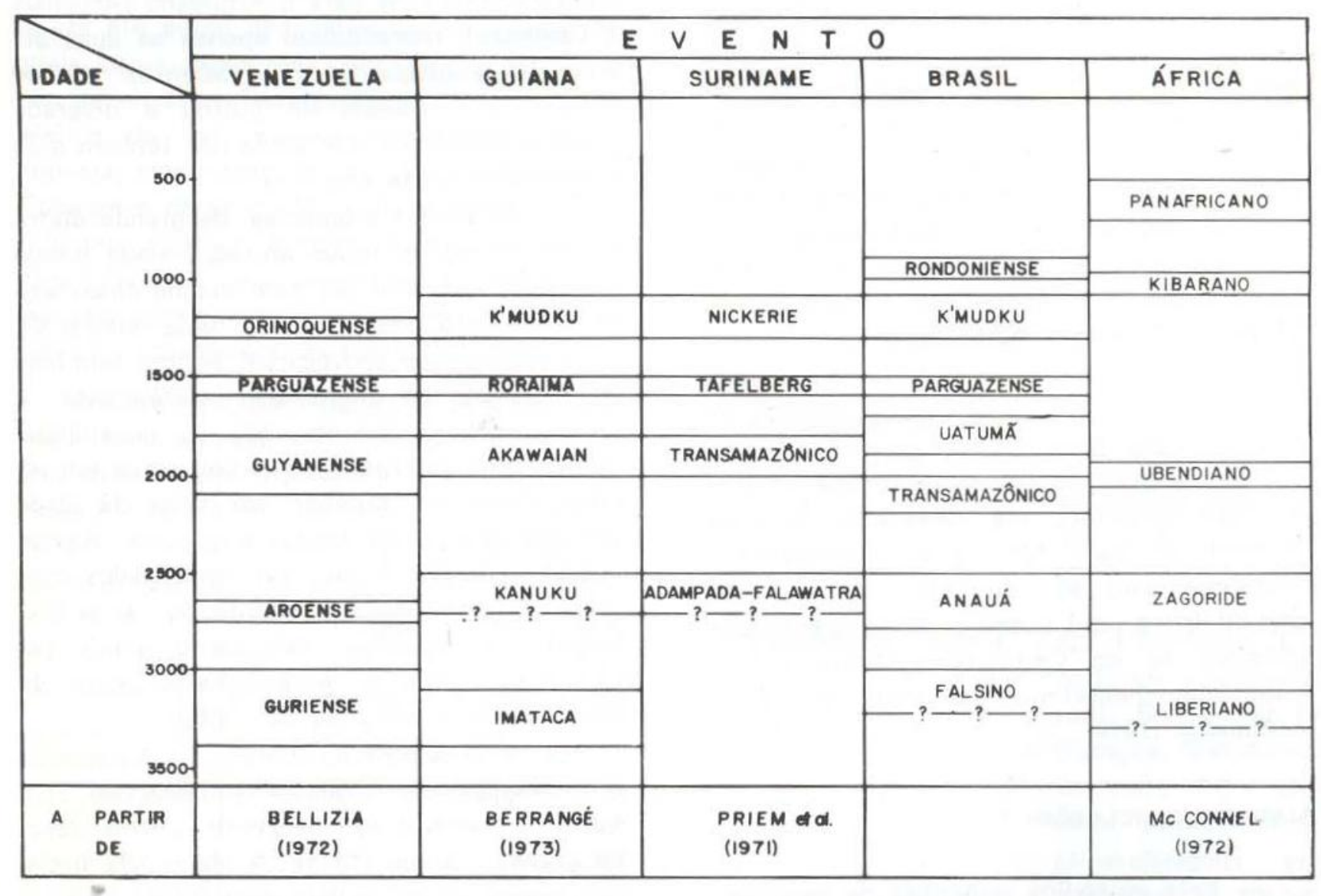

QUADRO V - Principais periodos de movimentaçảo no Pré-Cambriano na Amazônia, comparados com a Árica 
relacionáveis, Santos et al. (1977) demonstraram ser produto de uma manifestação bem definida temporalmente, a qual conduziu exclusivamente a formação de rochas básicas alcalinas, sem similares em toda a evolução da Plataforma Amazônica.

A idade admitida por Issler (1974), para o sienito Mutum, $1.026 \pm 28 \mathrm{~m}$.a., parece também corresponder ao episódio Rondoniense, pelo menos cronologicamente.

A Plataforma Amazônica parece não ter sido afetada pelo episódio Panafricano, caracterizado na região sul da África, cujas idades de manifestações situam-se entre 500 700 m.a., estando limitada a leste com a faixa de dobramentos Paraguai-Araguaia, do ciclo Brasiliano (Almeida, 1974), o qual parece corresponder ao Panafricano.

Portanto, a reativação tectônica Rondoniense situa-se como o último evento registrável no Proterozóico Superior, não ocorrendo, a partir dessa época $( \pm 1.000 \mathrm{~m}$.a.), até o início do Fanerozóico, nenhuma manifestação diastrófica caracterizável na região. Todavia, Almeida (1974) admite que determinadas coberturas pré-cambrianas, como Prainha, Sucunduri e Riozinho do Anfrízio, sejam brasilianas, ( 850 - 500 m.a.), e, conseqüentemente, correspondentes às coberturas Baikalianas do Escudo Báltico. Todavia, as duas primeiras unidades foram englobadas por Caputo et al. (1971) na Formação Prosperança e a última redefinida por Silva et al. (1974) como Formação Triunfo. Quanto à primeira, embora tenha sua idade mínima definida pelo seu contato com a base da Formação Trombetas (Ordoviciano Superior), sua idade máxima ainda necessita de maior número de informações e elementos para ser definida, havendo duas possibilidades para o seu posicionaınento cronológico: ou no Cambro-Ordoviciano, ou no Proterozóico Superior (Brasiliano), como admite Almeida (1974).

\section{ALgumas CONCLUSÕES}

- Sete episódios principais de movimentação tectônica podem ser reconhecidos na Plataforma Amazônica durante o Pré-Cambria- no, sendo uns de caráter orogênico e outros de evolução anorogênica. Tais episódios são relacionados abaixo, registrando-se as faixas de tempo de seus paroxismos:

$\begin{array}{lr}\text { Rondoniense } & 980 \pm 20 \mathrm{~m} . \mathrm{a} . \\ \text { K'Mudku } & \pm 1.200 \mathrm{~m} . \mathrm{a} . \\ \text { Parguazense } & 1.500-1.600 \mathrm{~m} . \mathrm{a} . \\ \text { Uatumã } & 1.700-1.900 \mathrm{~m} . \mathrm{a} . \\ \text { Transamazônico } & 2.000-2.200 \mathrm{~m} . \mathrm{a} . \\ \text { Aroensis } & 2.600-2.700 \mathrm{~m} . \mathrm{a} . \\ \text { Guriense } & 3.000-3.400 \mathrm{~m} . \mathrm{a} .\end{array}$

- A última orogênese que afetou a Plataforma Amazônica foi a Transamazônica, situada no Proterozóico Inferior, sendo que a partir dessa época, todo o diastrofismo registrado na região teve caráter anorogênico

- É bastante provável que os dois episódios assinalados para o Arqueano (Aroensis e Guriense), representem apenas as duas atividades orogenéticas mais intensas. sendo possível a existência de outros e diversos eventos tectônicos que ainda não tenham sido discernidos nessa era.

- As rochas arqueanas, de grande distribuição na região, foram afetadas ainda durante o Pré-Cambriano por pelo menos cinco episódios diastróficos principais (vide quadro V). mais jovens, que provocaram efeitos térmicos que variaram de intensidade ateralmente. É fácil perceber, portanto, que as possibilidades de uma determinação radiométrica em rochas arqueanas, receber um valor de idade próximo do real, são bastante remotas. Assim, outros critérios devem ser empregados conjuntamente no estabelecimento do limite Proterozóico/Arqueozóico, tais como índice petrogenético, grau de metamorfismo, estilo de dobramentos e relações de contato.

- A denominação Plataforma Amazônica é empregada, com algumas modificações, conforme o conceito de Susczynsky (1970), Amaral (1974) e Braun (1975). A identidade litológico/estrutural de ambas as bordas (norte e sul) da bacia páleo-mesozóica do Amazonas, bem como o registro de representantes do 
Grupo Uatumä no assoalho dessa seqüência sedimentar, no médio Amazonas, indicam claramente que a natureza dessa bacia é intracratônica e não intercratônica, cơmo a denominou Bigarella (1973). Dessa forma, os chamados Cráton das Guianas e Cráton do Guaporé pelo menos na sua maior parte, constituem um único bloco cratonizado desde o encerramento Proterozóico Inferior.

Assim, fundamentado nas definiçōes de Cráton e Escudo emitidas por Anhaeuser et al. (1969), o mais adequado é que as áreas pré-cambrianas ao norte e sul da bacia Amazônica, a exemplo do procedimento adotado pelo Projeto RADAM, sejam designadas, apenas para efeito de caracterização geográfica regional, respectivamente de Cráton das Guianas e Cráton Guaporé, abandonando-se o emprego do termo Escudo, o qual tem significado continental. Assim, a Plataforma ou Escudo Amazônico, seria constituída de dois crátons. Embora haja uma descontinuidade física, de natureza até então desconhecida no fundo daquela bacia, registrada por ondas sísmicas, não se observam nas camadas paleozóicas os efeitos de deformações relacionados com a suposta movimentaçăo dos blocos Guiana e Guaporé a partir do Mesozóico, como é sugerido por diversos autores, entre eles Guimarães (1970), o qual determinou o eixo dessa movimentação como localizado exatamente na cidade de Santarém, na foz do rio Tapajós.

Prefere-se supor, especulativamente, que essa descontinuidade esteja relacionada com uma maior espessura do SIMA na região coincidente com o fundo da bacia, a qual está sendo admitida como associada com extenso alinhamento de direção grosso-modo leste-oeste, o qual deve ter-se originado em tempos fanerozóicos (Mesozóico?) visto que parece não ter interferido na geometria e estrutura dos episódios pré-cambrianos.

- A maior parte dos principais episódios diastróficos que foram até o presente registrados na Plataforma Amazônica, encontram eventos correspondentes ou pelo menos correlacionáveis, no pré-Cambriano da Africa. Já em 1972 McConnell, na Guiana e Bellizzia, na
Venezuela estabeleceram comparações dos principais períodos de movimentação naquele continente, com os da Plataforma Amazônica (Quadro V). Assim, o Liberiano é correlacionável com o Guriense; o Zagoride com o Aroensis; o Ubendiano/Eburneano com o Transamazônico e, finalmente o Kibarano com o K'Mudku - Quadro V. Em contrapartida, o magmatismo dos ciclos Uatumã e Parguazense não encontra manifestação similar na Africa, ao passo que o evento Panafricano não atingiu a Plataforma Amazônica, podendo, contudo, ser comparado com o Brasiliano da faixa orogênica Paraguai-Araguaia.

- Comparações mais detalhadas entre a Plataforma Amazônica e a África somente poderão ser emitidas a partir de um razoável número de determinações de idade e análises químicas, ainda não disponíveis. Desse modo, especulações em torno da metalogenia associada a alguns dos episódios pré-cambrianos, devem ser encaradas como prematuras. Por outro lado, outros episódios têm sua geologia econômica esboçada de modo preliminar, tendo-se em vista ocorrências e jazimentos já conhecidos. Uma síntese da potencialidade econômica do Pré-Cambriano da Amazônia e sua comparação com a África será motivo de futura nota, podendo-se, presentemente, todavia, relacionar os principais elementos já conhecidos e passíveis de formar depósitos na região:

- Proterozóico Superior: $\mathrm{Sn}, \mathrm{Nb} / \mathrm{Ta}$ (Rondônia) Mineralizações em rochas alcalinas: $\mathrm{Nb}, \mathrm{T} . \mathrm{R} ., \mathrm{Th}, \mathrm{Zr}$, etc.

- Proterozóico Médio : Au e Diamante (Coberturas sedimentares) $\mathrm{Sn}$ e $\mathrm{Nb} / \mathrm{Ta}$ (Tapaj6s, Surucucus, Amapá), Mn e calcário (Beneficente), Mineralizações associadas a rochas alcalinas: $\mathrm{Nb}, \mathrm{T}$. R., $\mathrm{Th}, \mathrm{Zr}$, etc. 


$\begin{array}{ll}\text { - Proterozóico Inferior : } & \text { Mn (Amapá), Fe } \\ & \text { (Carajás), sulfetos } \\ & \text { em metavulcânicas } \\ & \text { (?). } \\ \text { - Arqueozóico } & : \text { Fe, Au (Tapajós), } \\ & \mathrm{Cr} \text { (?). }\end{array}$

\section{SUMMARY}

Amazonian Precambrian has been subdivided on three larger intervals: Upper, Middle and Lower, separated by the $2.600 \mathrm{~m}: \mathrm{y}$. and $1.800 \mathrm{~m}$.y ages. Many CPRM's works, together with RADAM Project informations, made possible a new subdivision for the Precambriam time. Thus, likewhise Canada, URSS, Australia, South Africa and China's scales, two major intervals compound Precambrian: Archaeozoic and Proterozoic. The former enclose two chief tectonic cycles, one of then take place at Lower Archaeozoic (over $3.000 \mathrm{m.y.)}$, called Guriense, and other related to Upper Archaeozoic (2.600 m.y. to $3.000 \mathrm{~m} . \mathrm{y}$.$) and$ named Aroense $(2.600 \mathrm{~m} . \mathrm{y}$. to $2.600 \mathrm{~m} . \mathrm{y}$.$) . Rocks$ belonging to granulite facies represents Guriense Cycle, like Imataca Complex in Venezuela, whereas anfibolitic belts as well as Anauá (Roraima), Cuiú-Cuiú (Pará): Moura (Amazonas), Kanuku (Guiana), Supamo (Venezuela) and Coeroeni (Suriname) where metamorfised during Aroense Cycle. In Lower Proterozoic (2.600 $\mathrm{m} . \mathrm{y}$. to $1.900 \mathrm{~m} . \mathrm{y}$.) Transamazonian Orogenic Cycle has been developed (2.000 to $2.200 \mathrm{~m} . \mathrm{y}$. ), producing many greenstone belts and itabiritic rocks like so called Cauarane (Roraima), Tunuí (Amazonas), Grão Pará (Pará), Vila Nova (Amapá), Barama (Guiana), Pastora (Venezuela), Armina (Suriname) and Orapu (French Guyana) Groups. This is the last orogeny to affect the Amazonian region, since thenceforth, all evolutive process in Plataform possessed cratogenic character. Two princlpals Plataform's reactivations took place during Middle Proterozoia, one at $\pm 1.800 \mathrm{~m} . \mathrm{y}$. (Uatumã), and other at $1.500 \mathrm{~m} . \mathrm{y}$. (Parguazense), well known by intensive acid magmatism. The boundary between Middle and Upper Proterozoic is established at $\pm 1.200 \mathrm{~m} . \mathrm{y}$., whith the Tectonic Episode K'Mudku development. Other important reactivation, make possible many plutonic intrusions, at the Upper Proterozoic beginning (Rondoniense granites), adjoining and closely related with alkalibasalt extrusion of the Pacaás Novos (Rondônla), Lábrea (Amazonas) and Cachoeira Seca (Pará) types. At the Proterozoic final, another and poor known reactivation may correspond to Brasilian Cycle, englosing alkalic magmatism (Guariba Alcalines) and arkose sedimentation (Prosperança Formation).

\section{BIBLIOGRAFTA CITADA}

AChĩo, S. M. \& SAzAs, H. T.

1974 - Prospecção geológica na Serra Tunuí. Manaus, CPRM (Relatório interno).
Almeida, F. F. M. DE

1974 - Evoluçăo tectônica do Cráton Guaporé, comparado com a do Escudo Báltico. Rev. Bras. de Geociência, São Paulo, 4(3) : 191204, il.

Almeida, F. F. M. et AL.

1968 - Radiometric age determinations from Northern Brazil. Bol. da Soc. Bras, de Geologia, 17(1).

Amaral, G.

1970 - Precambrian evolution of Amazon Region. Resumos do 19 Congr. Lat. Aem. Geol., p. 77-78,

1974 - Geologia Pré-Cambriana da Regiăo Amazônica. 212 p. il.

Anhaeusser, C. R. et al.

1960 - A Reapraisal of some aspects of Precambrian Shield geology. Geological Society of America Bulletin, 80 : 2175-2200.

araújo Neto, H. \& Moreira, H. L.

1976 - Projeto Estanho de Abonari; Relatório final. In: Brasil. Ministério das Minas e Energia. Departamento Nacional de Produção Mineral. Convênio DNPM-CPRM. Relatório inédito. $2 \mathrm{v}$.

BARRON, C. N.

1966 - Notes on the stratigraphy of Guyana. Geological Survey of Guyana. 27 p., il.

BAsei, M. A. S.

1973 - Geocronologia : SB22/SC.22. Belém, Projeto RADAM, $3 \mathrm{p}$.

BEISIEgEL, V. DE R. ET AL.

1973 - Geologia e recursos minerais da Serra dos Carajás. Rev. Bras. de Geociências, 3: 215242 , II.

Bellizzia, C. M.

1972 - Paleotectonica del Escudo de Guayana. In : Memória de la novena Conferência geologica Interguayanas, mayo 714 . Puerto Ordaz, Venezuela. p. 251-305, il.

BERRANGÉ, J. P.

1973 - A synopsis of the geology of Southern Guyana. London, Institute of Geological Sciences, Report, 26 : 1-16, il.

BOMFIM, L. F. C. ET AL.

1974 - Projeto Roraima; relatório final; folha NA.20Z-B. In: Brasil. Departamento Nacional da Produção Mineral, Convênio CPRN, vol. 9, il.

BraUN, O. P. G.

1975 - Aspectos geológicos das acumulaçōes minerais na área Norte da Amazônia e conside. rações sobre sua pesquisa. In: 10. Conferência Geológica Interguianas, Resumo. v. 2, p. 13 .

BURWASH, R. A.

1969 - Comparative Precambrian geochronology of the North American, European, and Siberian shields Canadian Journal of Earth Sicnences, $6(3)$ : $357-365$, il. 
Caputo, M. V. et al.

1971 - Litoestratigrafia da Bacia do Amazonas. Belém, Petrobrás-renrel. 641-A, out. il.

ChOUBert, B.

1964 - Ages absolus du Precambrien guyanais. Comp. Rend. Acad. Sci. Fr., 258 : 631-634.

ClifFord, J. C.

1967 - The Damaran episode in the upper Proterozoic-lower Paleozoic structural history of Souther Africa. Geol. Soc. America Special Paper, 92 : 1.69.

Costa, J. L. ET AL.

1974 - Projeto Norte da Amazônia; Domínio Oiapoque-Jari; relatório final integrado. In : Brasil : Departamento Nac. da Produção Mineral, Convênio, CPRM, v. 5.

DUNN, P. R, ET AL.

1966 - A prososal for time-stratigraphic subdivision of the Australian precambrian: J. Geol. Soc. Austral., 13(2).

ENGel, A. E. J. ET AL.

1974 - Crustal evolution and global tectonics : a petrogenic view. Geological Society of America Bulletin, 85(6) : 843-858.

GEOMINERAÇÃo

1972 - Pesquisa Mineral no Iriri/Curuá. Relatório preliminar. SUDAM/DRN/DRM, 62 p., il.

GerLing, E. ET AL.

1968 - Precambrian geochronology of the Baltic Shield. In : Intern. Geol. Congre., Rept. 23. Session, Proc. Sect., 4, 265-273.

GOLDISH, S. S.

1969 - Geochronology in the Lake Superior Region. In: Burwas, R. A. - Comparative precambrian geochronology of the North American European and Siberian shields. Canadian Journal of Earth Sciences, 6(3) : 357-365 .

GUIMARÃES, D.

1970 - Gênese da Bacia Amazônica. DNOM-SGM, Notas preliminares e estudos (149): 1-6.

Hebeda, E. H. et al.

1973 - Excess radiogenic argon in the Precambrian Avanavero Dolerito in western Suriname (South America). Earth \& Plan. Sci. Letters, 20(2) : $189-200$.

HURLey, P. M. et al.

1968 - Some orogenic episodes in South America by K-AR and Wholeroelck RB-SR dating. Canadian Journal of Earth Sciences," $5(4)$ : 633-638.

1973 - Progress report on age dating in the Northern Guayana Shield (abs). In : 119 Congr. Lat. Amer. Geol., v. 1.

ISSLER, R. S.

1974 - Esboço geológico tectônico do Cráton do Guaporé. Projeto RADAM, relatório. In : 28. Congresso Brasileiro de Geologia, Porto Alegre.
ISSLER, R. S. ET AL

1974 - Geologia da folha SA.22-Belém. In: Brasil. Departamento Nacional da Produção Mineral. Projeto RADAM. Folha SA.22-Belém. (Levantamento de Recursos Naturais).

JAMES, $\mathrm{H}$.

1972 - Subdivision of Precambrian : a interim scheme to be used by U.S. Geological Survey. In: Smikhatov, M. A. - A general stratigraphic scale for the upper Pre-cambrian : present state and future prospects. International Geology Review, 16(11) : 1242-1254 .

KALLIOKOSKI, J.

1965 - Geology of North Central Guayana shield Venezuela. Geological Society of America Buelletin, 7 : 1027-1049, il.

LiberATORE, G. ET AL.

1972 - Projeto Aripuanã-Sucunduri; relatório final. In : Brasil. Ministério das Minas e Energia DNPM-CPRM. Relatório iriterno no 016. $85 \mathrm{p}$.

LIMA, M. I. DE ET AL.

1974 - Folha NA/NB, 22-Macapá. In : Brasil. Departamento Nacional da Produção Mineral. Projeto RADAM, 6 (Levantamento de Recursos Naturais).

LOCZY, L. DE

1973 - Some problems of the tectonic framework of the Guiana shield with special regard for the Roraima formation. Geologischen Rundschau, Stuttgart, 62(2): 318-342.

MCCONNELL, R. B.

1972 - Las formaciones precambricas de Africa y del Escudo de Guayana en relacion con la Deriva Continental. In: Memoria de la Novena Conferência Geológica Inter-Guayanas, mayo, 7-14.

MCCONNELl, R. B. \& Williams, E.

1970 - Distribution and provisional correlation of precambrian of the Guiana shield. In : Proceedings of the Eighth Guiana Geological Conference, Georgetown, 11-15 aug., 1969. Geological Survey. p. 1-22.

Mandetta, P.

1970a - Datações geocronológicas de rochas do $T$. F. de Roraima. In Brasil. Ministério das Minas e Energia, DNPM, 59 Distrito, Relatório 75 : mai./jul., $14 \mathrm{p}$.

1970b - Reconhecimento geológico dos rios Auaris, Parima, Aracacá e Uraricuera. In: Brasil. Ministério das Minas e Energia. DNPMCPRM, Relatório inédito, Manaus, $18 \mathrm{f}$. il.

Mandetta, P. et al.

1974 - Reconhecimento geológico e geoquímico ao longo do rio Pitinga, afluente do rio Uatumã. Manaus, CPRM, relatório interno. $31 \mathrm{f}$. 
MENDOZA, V. ET AL.

1975 - Evolucion geoquímica de rocas graníticas de la Guayana Venezolana. In: 10. Conferência Geológica Inter-Guianas.

Montalvão, R. M. G. DE

1975 - Grupo Uatumã no Cráton Guianês. Brasil. Ministério das Minas e Energia. DNPMRADAM, relatório interno. In : 10. Conferência Gelógica Inter-Guianas, nov.

Montalvão, R. M. G. et al.

1975a - Formação Tuini. In : Lessa Sobrinho, M. \& Braga, J. C. - Anteprojeto Seis Lagos. Brasília, DNPM-DGM.

1975b-Geologia. In: Brasil. Departamento Nacional da Produção Mineral Projeto RADAM/ BRASIL. Folha NA. 20-Boa Vista e parte das folhas NA-21-Tumucumaque, NB.20-Roraima e NB.21. Rio de Janeiro, 8 (Levantamento de Recursos Naturais).

PEsSOA, M. R. et al.

1977 - Projeto Jamanzxim; Relatório final. Manaus, DNPM/CPRM. 7 v. (Rel. inédito).

PINHEIRO, S. DA S. ET AL.

1976 - Geologia. In: Brasil Departamento Nacional da Produção Mineral. Projeto RADAM. Folha NA. 19 Pico da Neblina. v. II (Levantamento de Recursos Naturais).

PRIEM, H. N. A. et AL.

1909 - Isotopic geochronology in Suriname. In : Guayana Geolog'cal Conference, 8., Georgetown. Proceedings. Georgetown.

1971 - Isotopic ages of the trans-Amazonian acidic magmatism and the Nickerie metamorphic episode in the Precambrian basement of Suriname, South America. Geological Society of America Bulletin, Colorado, 82 : 1667-1667.

1973 - Age of the Precambrian Roraima Formation in North Eastern South America. Evidence from isotopic dating of Roraima pyroclastic volcanic rocks in Suriname. Geological Society of America Bulietin, Amsterdam, 84 : 1677-1864, may.

RAmgrab, G. E. \& Damiño, R. N.

1970 - Reconhecimento geológico dos rios Anauá e Barauana; Território Federal de Roraima. Manaus, DNPM-59 Distrito - Norte. Relatório inédito $36 \mathrm{p}$.

RAMgrab, G. E. et al.

1972 - Projeto Roraima; $2^{\text {a }}$ fase. In : Brasil. Ministério das Minas e Energia. DNPM-CPRM. Relatório interno. Manaus, $n$ \% 014, v. 9.

REID, A. R.

1972 - Strätigraphy of the type area of the Roraima group, Venezuela. In: Memoria de la Novena Conferência Interguyanas, mayo 7-14, Puerto Ordaz, Venezuela, p. 343-353.
SANTOS, D. B. DOS ET AL.

1975 - Folha SB.21-Tapajós. In: Brasil. Departamento Nacional da Produçăo Mineral. Projeto RADAM. Rio de Janeiro, 7 (Levantamento de Recursos Naturais)

SANtos, J. O. S. et al.

1974 - Projeto Norte da Amazônia, domínio Baixo Rio Negro; relatório final integrado. Brasil. DNPM. Convênio CPRM, Manaus: v. 4.

SEMENenKo, N. P. ET AL.

1969 - Geochronology of the Ukranian precambrian. Canadian Journal of Earth Sciences, $6(2): 357-365$.

Semikhatov, M. A.

1974 - A general stratigraphic scale for the upper Precambrian: present state and future prospects. International Geology Review, 16(11): 1242-1254, nov.

Silva, G. G. DA Et AL.

1974 - Geologia das folhas SB.22-Araguaia e parte de SC.22-Tocantins. In: Brasil. Departamento Nacional da Produção Mineral. Projeto RADAM, Rio de Janeiro. (Levantamento de Recursos Minerais)

SNelling, N. J. \& MCCONNell, R. B.

1969 - The geochronology of Guyana. In: 7 . Inter. Guiana geol. Conf., Paramaribo, 46: $1-20$.

SNelling, N. J. \& Berrangé, J. P.

1970 - The goechronology of Guyana II. Results obtained in the period 1966/1969. In : Proceedings of the Eighth Guiana Geological Conferênce, Georgetown, p. IV-1/20 t IV$15 / 20$.

StockWell, C. H.

1960 - Geochronology of stratified rocks of the Canadian shields. Canadian Journal of Earth Sciences, 6(3) : 357-365, jun.

1974 - Revised Precambrian time scale for the Canadian shield. International Geology Review, 16(11) : 1242-1254.

SUSCZYNSKI, E. F,

1970 - La géologie et tectonique de la plateforme Amazoniense. Geologische Runschan, 59(3) : 1232-1253.

Teixeira, W. \& TASSinari, C. C. G.

1976 - Geocronologia e consideraçöes preliminares sobre a evolução geológica da folha NA.21Pico da Neblina. Projeto RADAM/BRASIL. (Relatório interno, 67-G). $12 \mathrm{p}$.

TORRES, G. A.

1975 - El complejo de Itamaca en los alrededores de Cerro Bolivar. Estado Bolivar, Venezuela. Caracas. In: Anais da 10. Conferência Geológica Inter-Guianas, Belém, nov. 
VeRsChURE, R. H. \& BON, E. H.

1972 - Geology and geochronology of tin-bearing volcanoplutonic complexes in Rondô.nia, (western Brazil), reflections on the genesis of this type of magmatism. Z.W. O. Laboratorium voor Isotopen-Geologie, Progress Report, sept. I, 1970, aug. 31 p. 177-198.
Williams, E. et al.

1967 - The folded precambrian of northern Guyana related to the geology of the Guyana Shield. Geol. Surv. Guyana. Records 5:60.

(Aceito para publicação em 05/01/78) 